Journal of Contemporary Research in Business, Economics and Finance

ISSN: 2641-0265

Vol. 1, No. 4, pp. 62-73

2019

Publisher: Learning Gate

DOI: 10.33094/26410265.2019.14.62.73

(C) 2019 by the authors; licensee Learning Gate

\title{
Organizational Justice and Employee Deviance among Emergency Services Personnel in Malaysia
}

\author{
Leong Weng, Lee \\ PhD student, School of Graduate Studies, Asia e University, Kuala Lumpur, Malaysia \\ Muhammad Madi bin, Abdullah \\ Associate Professor, University College of Technology Sarawak, Sibu, Sarawak, Malaysia
}

Received: 17 October 2019; Revised: 6 November 2019; Accepted: 21 November 2019; Published: 9 December 2019

\begin{abstract}
Fairness in the workplace is imperative in the emergency services sector. Most of the organizational justice and workplace deviance literature addresses the non-emergency services perspective, while research involving the emergency services personnel have been lacking. The aim of the present study is to examine the relationship between emergency services personnel perception of organizational justice and employee deviance. A cross-sectional field survey was conducted utilizing a sample of 209 in 10 Emergency Services Centers in Malaysia. Employees rated fairness in the distribution of outcomes and rewards (distributive justice), fairness in interaction with managers (interpersonal justice) and candid explanation (informational justice), fairness in procedures implementation (procedural justice) and the frequency to exhibit deviant behaviors at work (employee deviance). Analysis results revealed that low levels of interpersonal justice and informational justice predicted deviant acts targeted at other individuals, while low levels of distributive justice and informational justice predicted deviant acts targeted at the organization. This study adds to the growing body of research on employee deviance literature by empirically validating the workplace deviance typology in an emergency services setting and by examining four types of organizational justice simultaneously on employee deviance.
\end{abstract}

Keywords: Organizational justice, Deviance, Emergency services.

\section{Introduction}

According to Greenberg (1990), organizational justice refers to an employee's perception of the fairness of their organization's behaviour, decisions and actions. Past studies have found justice at work is related to work outcomes such as high levels of organizational citizenship behaviour, work performance, job satisfaction, and low levels of workplace deviance (Alias and Rasdi, 2015; Deconinck and Johnson, 2013; McCain, Tsai, and Bellino, 2010; Moorman, 1991; Niehoff and Moorman, 1993). In an emergency services setting, it is important for the managers to avoid creating an unjust work environment which may lead to high deviance amongst the volunteers.

Fairness at work also relates to a broader problem. The workplace deviance literature contains a broad range of studies on what may influence an employee to engage in deviant acts. Some studies have found that fairness perceptions concerning the distribution of outcomes and rewards predicted organizational deviance (Ambrose, Seabright, and Schminke, 2002; Aquino, Lewis, and Bradfield, 1999; Chang and Smithikrai, 2010; Lim, 2002), whereas the perception of fairness in interaction and informational communication will predict interpersonal deviance (Henle, 2005; Liu and Ding, 2012). However, most of the published literature addresses the full-time or contractual employee's perspective. There is limited research on emergency services personnel perceptions of organizational justice and its implications on workplace deviance. As emergency services organizations highly rely on their 
employees to run daily operations, their perspective is important to managers for a better understanding of their employees, improving and evaluating the conduciveness of the work environment as well as to encourage these employees to continue servicing their local communicaty and public. This is relevant to the Malaysian emergency services because it is one of the nation's largest providers of emergency services to provide immediate first aid, ambulance services, post-emergency relief and redevelopment of disaster site and other humanitarian services.

Although past studies have attempted to quantify the relationship between organizational justice and employee deviance (Liu and Ding, 2012; Chang and Smithikrai, 2010; Henle, 2005; Ambrose et al., 2002), only a few local studies have attempted to examine how perception on organizational justice may contribute to the development of deviant behaviours (Nasurdin, Ahmad, and Razalli, 2014; Hemdi and Aizzat, 2006). To our knowledge, this study is the first to validate the constructs of organizational justice and employee deviance as well as to examine the relationship between the emergency services personnel perception of organizational justice and their likelihood to exhibit employee deviance.

\section{Literature Review}

Past studies have identified the dimensions in organizational justice as one of the antecedents of employee deviance from Adam's (1965) equity theory and social exchange perspective (Cropanzano and Mitchell, 2005; El Akremi, Vandenberghe, and Camerman, 2010; Parzefall and Salin, 2010). Equity theory suggested an assumption that how much people are willing to contribute to an organization depends on their assessment of the fairness, or equity, of the rewards they will receive in exchange. Equity theory stated that if a person perceives an inequity, tension or drive will develop in the person's mind, and that person will be motivated to reduce or eliminate the tension and perceived inequity.

In this respect, perceived fairness of job demands and outcomes a person received, perceived fairness of the processes and procedures used to make decisions regarding the allocation of workloads and outcomes, perceived that the organization treats them with respect, and effective communication of information should drive away workplace deviance. Hemdi and Aizzat (2006) tested the theory by emphasizing the belief of injustice associated with outcomes will invoke one's feelings of dissatisfaction and resentment that motivate aggrieved individual to violate organizational norms and commit acts of deviance.

Social exchange theory explained how relationships are initiated and sustained through the reliable exchange of rewards and the imposition of costs between individuals (Parzefall and Salin, 2010). The theory had suggested that employees work for an organization in exchange for direct, concrete rewards such as pays, goods, and services as well as indirect, socio-emotional rewards such as status and admiration (O'Boyle, Forsyth, Banks, and McDaniel, 2012; Settoon, Bennett, and Liden, 1996). These exchanges create relationships between among employees and employers, which strengthen when (a) the rewards are valued ones, and any costs created by the relationships are minimized; (b) exchange partners trust each other to fulfil their obligations over the long term; (c) the exchange is judged to be fair one, with fairness defined primarily by mutual adherence to the norm of reciprocity; and (d) both parties develop a psychological commitment to the relationship, as indicated by increased affective attachment, a sense of loyalty, mutual support, and an authentic concern for the other's well-being (Cropanzano and Mitchell, 2005; O'Boyle et al., 2012).

Equity theory was proposed by Adams (1965) to assess outcome fairness which serves as the basis of distributive justice domain; social exchange theory Blau (1964), suggests that people expect loyalty and effort on behalf of their employer to be reciprocated in ways other than just pay and benefits; they expect less tangible rewards, such as respect, appreciation, and fair procedures.. In Colquitt's (2001) meta-analysis, each dimension of organizational justice has a unique relationship with different organizational outcomes such as job satisfaction, organizational commitment, organizational citizenship and performance.

Studying specific forms of justice will provide an avenue to the organization to identify elements that might be lacking in some area and then recommend changes to either the procedures or the 
behaviour of those involved in order to enhance the overall perception of organizational justice. Moreover, previous empirical studies have debated about the dimension of interactional justice to determine whether interactional justice is a single dimension (Cohen-Charash and Spector, 2001), two dimensions (Interpersonal Justice and Informational Justice) (Colquitt, Conlon, Wesson, Porter, and Ng, 2001; Colquitt, 2001) or three dimensions (Interactional Justice, Interpersonal Justice and Informational Justice) (Roch and Shanock, 2006).

The contribution of this study lies in its ability to identify empirical patterns of association that are unique to each dimension of the employee deviance, as well as associations that are shared across organizational justice on employee deviance.

Given previous research into these dimensions of organizational justice, it is predicted that the four dimensions of organizational justice will be correlated with different forms of employee deviance.

\subsection{Employee Deviance}

The research on employee deviance has highlighted the pervasiveness of wrongdoing acts at workplace amongst the employees (Appelbaum, Deguire, and Lay, 2005; Bennett and Robinson, 2000; Judge, Scott, and Ilies, 2006; Ménard, Brunet, Savoie, Van Daele, and Flament, 2011; O’Neill, Lewis, and Carswell, 2011) particularly from the Western scholars. Employee deviance is defined as an individual's voluntary behaviour that violates significant norms, and in doing so, threatens the well-being of an organization, its members, or both (Bennett and Robinson, 2000).

Bennett and Robinson (2000) have classified workplace deviance into interpersonal and organizational deviance which is to differentiate the wrongdoing acts based on the targets. Interpersonal deviance is targeted at members of the organization such as playing a prank on someone at work. On another hand, organizational deviance refers to acts that directed at the organization and included behaviours such as sabotaging equipment and intentional errors or delays in work. In the metaanalysis work by Berry, Ones and Sackett (2007), these forms of workplace deviance may differ from each other in terms of their antecedents.

Therefore, in order for an organization to adopt far more effective preventive work policies to inhibit different forms of workplace deviance amongst the employees, examining whether different dimensions of organizational justice will have a different degree of effect on interpersonal deviance and organizational deviance is necessary, especially in the emergency services setting.

\subsection{Organizational Justice and Employee Deviance}

The term organizational justice explains the rules of fairness which directly relates to the workplace (Hassan and Hashim, 2011). Organizational justice is concerned with the ways that employee ascertain if they are treated fairly inside their jobs along with the ways in which those determinations have an effect on other work-related variables (Moorman, 1991). Colquitt's (2001) meta-analysis had demonstrated that organizational justice, such as Distributive Justice, Procedural Justice, and Interactional Justice are positively related to employee's satisfaction, organizational trust and job performance. Among the consequences of organizational justice, the negative job performance such as workplace deviance has been a hot research topic (Bauer and Spector, 2015; Peng, 2008; Narveson, 2006).

Moreover, in the emergency services setting, some employees might have to accept riskier tasks which could be threatening their own safety. For example, they place their own lives at risk when employees work at a disaster site (e.g., performing search and rescue operations) and/or provide first aid at emergency situations. Any mishap, they might get injured or killed while saving lives.

Aquino, Lewis and Bradfield (1999) have demonstrated that distributive justice is negatively correlated with interpersonal deviance but not organizational deviance. On another hand, Henle (2005) found distributive justice is negatively correlated with both dimensions of workplace deviance, while Alias and Rasdi (2015) found distributive justice has a negative correlation with organizational deviance. Given that research has found significant negative relationships between distributive justice and both forms of workplace deviance, we hypothesize the following: 
Hypothesis 1: Distributive justice will be negatively related to i) interpersonal deviance and ii) organizational deviance.

Procedural justice means the fairness of the formal procedures and processes of organizational decision making (Greenberg, 1990). Greenberg (1994) found that staff members perceived the presence of procedural justice when supervisors provide ample explanations for his or her decision. Occasionally, emergency services management might bring in certain rules without due concern intended for employees. For example, in recent cost cutting implementation, many emergency services personnel were required to work longer hours for a period of six months but were not informed that they would not be paid for the extra hours they worked.

It can be understandable that emergency services wanted to save the operating costs in order to become sustainable. However their supervisors really should have explained to their employees that the cost cutting implementation before proceed with their duty schedules as usual. Moreover, past studies have shown procedural justice is negatively related to workplace deviance (Aquino et al., 1999; Hemdi and Aizzat, 2006). Therefore, it is hypothesized that:

Hypothesis 2: Procedural justice will be negatively related to 1) interpersonal deviance and ii) organizational deviance.

Interactional justice indicates the quality of communication between the employee and the management which includes his or her superiors and colleagues (Henle, 2005). If volunteers perceived a high level of interactional justice, they would perceive that the organization treats them with respect; therefore, they are less likely to engage in workplace deviance. Greenberg (1993a) brought a new perspective of interactional justice by suggesting two specific types Interactional Justice, namely interpersonal justice and informational justice.

Interpersonal justice refers to the degree to which people are politely treated with dignity and respected by their supervisors, while informational justice is reflected in the candid explanations provided by their supervisors that convey information about why such procedures were used in a certain situation (Colquitt, 2001). However, few studies have distinguished if interactional justice (El Akremi et al., 2010; Greenberg, 1993b; Roch and Shanock, 2006) is a bi-dimension or single dimension. Thus, in this study, we propose that there are two dimensions of interactional justice (Colquitt, 2001), and it is hypothesized that:

Hypothesis 3: Interpersonal justice and informational justice will be negatively related to i) interpersonal deviance and ii) organizational deviance.

\section{Methodology}

The goal of this study was to examine the relationship between the emergency services personnel perception of organizational justice and their likelihood to engage in employee deviance. This crosssectional study utilised two stages of multi-cluster random sampling to determine the sample. At the first stage, 10 emergency services centres in Malaysia were randomly selected by the managing director and, the second stage was a random selection of 40 samples of volunteers from each state. According to the managing director of emergency services, there were approximately 2000 employees in Malaysia and all employees in chosen centres were invited as respondents in order to answer the research objective of this study.

400 survey questionnaires were distributed to gather primary data at 10 selected emergency services centers in Malaysia. The employees of these 10 centres have agreed to participate in the study, which resulted in 209 responses, yielding a respond rate of $53 \%$. Selection criteria used to gather responses from emergency services personnel is they are involved in emergency services activities whether as an emergency responder or administrative officer in one the selected emergency services centers in Malaysia.

The study was carried out using pencil and paper questionnaires and collected by the researcher at each centre. Prior to data collection, the researcher had contacted the managing director for permission 
to conduct a study. The managing director had approved the application, and a letter was issued. The authors proceeded to contact the supervisors at each respective centre for arrangements to meet their employees.

The participants were assured that the data collected are strictly confidential, anonymous and data protected. Each self-administered questionnaire was attached together with a pencil, a token of appreciation and an envelope to seal their anonymity while returning the questionnaire. In additions, participants were also allowed to take the questionnaire out of their workplace to ensure that the surveys were truly anonymous and to protect themselves.

Table 1.

Socio-demographic characteristics of respondents

\begin{tabular}{|l|l|l|l|}
\hline Demographic variables & Categories & Frequency & Percentage \\
\hline Sex & Male & 105 & 54.1 \\
\hline & Female & 89 & 45.9 \\
\hline Marital Status & Currently single & 139 & 71.6 \\
\hline & Married & 55 & 28.4 \\
\hline Educational Level & O'Level and below & 142 & 73.2 \\
\hline & Certificate/ Diploma & 44 & 22.7 \\
\hline & Degree & 8 & 4.1 \\
\hline Age (year) & Mean & Standard Deviation \\
\hline Tenure (year) & 27.55 & 9.31 & \\
\hline
\end{tabular}

The instruments to measure both volunteers' perception of organizational justice and employee deviance constructs were adopted from Colquitt (2001) and Bennett and Robinson (2000) respectively. The organizational justice scale by Colquitt (2001) was administered to measure the perceived level of organizational justice by the participants.

The scale included four items for distributive justice, four items for interpersonal justice, five items for informational justice and seven items to measure procedural justice. The respondents were asked to indicate their agreement on each item using a five-point Likert scale with response options ranging from 1 (strongly disagree) to 5 (strongly agree). Bennett and Robinson's (2000) 19 items measure of workplace deviance were used to measure the frequency of workplace deviance. There are seven items measuring interpersonal deviance and 12 items to measure organizational deviance using a seven-point Likert scale from 1 (never) to 7 (frequently).

The data set was screened using SPSS version 20.0 and results indicated no violations of the assumptions of normality, homogeneity, and linearity. Table 2 illustrates the result of the descriptive analysis to determine the mean of organizational justice and employee deviance. Results have indicated that "cursed someone at work" scored the highest mean value of 1.994 for interpersonal deviance, while "taken an additional or longer break than is acceptable at your workplace" scored the highest mean value of 1.679 for organizational deviance.

Confirmatory Factor Analysis (CFA) using AMOS version 19.0 was conducted on organizational justice and workplace deviance. Eight out of 19 items in workplace deviance and two out of 20 items in organizational justice constructs were dropped to allow the data set to fit into the measurement model. 
Table 2a.

Descriptive Analysis on workplace deviance and organizational justice scale

\begin{tabular}{|c|c|c|}
\hline Statement & Mean & SD \\
\hline \multicolumn{3}{|l|}{ Interpersonal Deviance } \\
\hline Made fun of someone at work* & 1.717 & 1.077 \\
\hline Said something hurtful to someone at work & 1.772 & 0.922 \\
\hline Made an ethnic, religious or racial remark at work* & 1.318 & 0.775 \\
\hline Cursed at someone at work* & 1.994 & 1.103 \\
\hline Played a mean prank on someone at work & 1.413 & 0.776 \\
\hline Acted rudely toward someone at work & 1.347 & 0.699 \\
\hline Publicly embarrassed someone at work & 1.249 & 0.629 \\
\hline \multicolumn{3}{|l|}{ Organizational Deviance } \\
\hline Taken property from work without permission & 1.179 & 0.541 \\
\hline Spent too much time fantasising or daydreaming instead of working* & 1.601 & 0.921 \\
\hline Falsified a receipt to get reimbursed for more money than you spent* & 1.087 & 0.422 \\
\hline Taken an additional or longer break than is acceptable at your workplace* & 1.679 & 0.88 \\
\hline Come in late to work without permission & 1.592 & 0.844 \\
\hline Littered your work environment* & 1.506 & 0.842 \\
\hline Neglected to follow your supervisor instruction & 1.387 & 0.731 \\
\hline Intentionally worked slower than you could have worked & 1.474 & 0.784 \\
\hline Discussed confidential information with an unauthorized person & 1.228 & 0.602 \\
\hline Used an illegal drug or consumed alcohol on the job & 1.066 & 0.363 \\
\hline Put little effort into your work & 1.309 & 0.668 \\
\hline Dragged out work in order to get overtime* & 1.24 & 0.666 \\
\hline \multicolumn{3}{|l|}{ Distributive Justice } \\
\hline Does your allowance reflect the effort you have put into your work? & 3.694 & 1.087 \\
\hline Is your allowance appropriate for the work you have completed? & 3.685 & 1.088 \\
\hline Does your allowance reflect what you have contributed to the organization? & 3.653 & 1.099 \\
\hline Is your allowance justified, given your performance? & 3.769 & 1.046 \\
\hline \multicolumn{3}{|l|}{ Interpersonal Justice } \\
\hline Has your supervisor treated you in a polite manner? & 3.844 & 0.935 \\
\hline Has your supervisor treated you with dignity? & 3.887 & 0.958 \\
\hline Has your supervisor treated you with respect? & 3.899 & 0.913 \\
\hline Has your supervisor refrained from improper remarks or comments? & 3.679 & 1.076 \\
\hline \multicolumn{3}{|l|}{ Informational Justice } \\
\hline Has your supervisor been candid in his or her communications with you? & 3.858 & 0.972 \\
\hline Has your supervisor explained the procedures thoroughly? & 3.916 & 0.902 \\
\hline Were your supervisor explanations regarding the procedures reasonable? & 3.890 & 0.888 \\
\hline Has your supervisor communicated details in a timely manner? & 3.844 & 0.910 \\
\hline $\begin{array}{l}\text { Has your supervisor seemed to tailor his or her communications to individuals' specific } \\
\text { needs? }\end{array}$ & 3.884 & 0.928 \\
\hline \multicolumn{3}{|l|}{ Procedural Justice } \\
\hline Have you been able to express your views and feelings during those procedures? & 3.624 & 0.994 \\
\hline Have you had influence over the decision arrived at by those procedures? & 3.468 & 0.933 \\
\hline Have those procedures been applied consistently? & 3.751 & 0.886 \\
\hline Have those procedures been free of bias? & 3.514 & 0.979 \\
\hline Have those procedures been based on accurate information?* & 3.887 & 0.803 \\
\hline Have you been able to appeal the decision arrived at by those procedures?* & 3.838 & 0.829 \\
\hline Have those procedures upheld ethical and moral standards? & 3.977 & 0.868 \\
\hline
\end{tabular}

*Item dropped after CFA conducted

Table 2 presented the values of the average variance extracted (AVE) and composite reliability (CR) values. These statistics were considered satisfactory, and they concur with Hair, Anderson, Tatham and

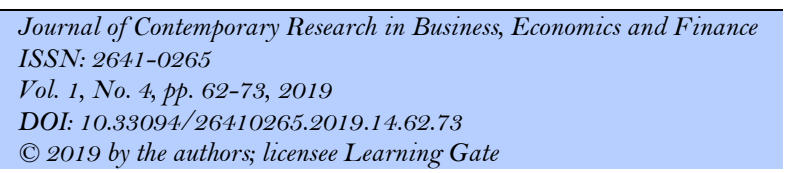


Black (2010) who recommend a minimum required level of AVE $>0.5$ and $\mathrm{CR}>0.7$ respectively. Results from the measurement model indicate that the hypothesized models fit the data well $\left(\chi^{2} / \mathrm{df}=1.646\right.$, GFI $=0.905$, AGFI $=0.882$, CFI $=0.960$, TLI $=0.954$, RMSEA $=0.043)$. Since the fit indices of the measurement model provide an acceptable fit to the data set, therefore it is surmised that it can be used for hypotheses testing.

Table $2 b$.

Average Variance Extracted and Composite Reliability of Constructs

\begin{tabular}{|l|l|l|l|}
\hline Construct & No. of items & Average Variance Extracted & Composite Reliability \\
\hline Interpersonal Deviance & 4 & 0.710 & 0.78 \\
\hline Organizational Deviance & 7 & 0.649 & 0.78 \\
\hline Distributive Justice & 4 & 0.853 & 0.94 \\
\hline Interpersonal Justice & 4 & 0.808 & 0.90 \\
\hline Informational Justice & 5 & 0.854 & 0.95 \\
\hline Procedural Justice & 5 & 0.664 & 0.75 \\
\hline
\end{tabular}

Descriptive statistics such as mean scores, standard deviations, reliabilities and inter-correlations of the study variables were computed for Table 3. The mean value for interpersonal deviance is 1.42 with a standard deviation of 0.56 , and the mean score for organizational deviance is 1.32 with a standard deviation of 0.46 . The mean scores have indicated a low level of workplace deviance among the volunteers. The mean values for the DJ, IJ, InfoJ and PJ were 3.70, 3.83, 3.88 and 3.67 respectively. These mean values have indicated that respondents in this study perceived a high level of organizational justice. In terms of correlations, IJ and InfoJ have a significant and negative relationship with interpersonal deviance, while DJ and InfoJ were found to be negatively correlated with organizational deviance. The inter-correlation values also concluded that there is no potential multicollinearity problem (Tabachnick and Fidell, 2013).

Table 3.

Means, Standard Deviations, Reliabilities, and Correlations between Study Variables ${ }^{\mathrm{a}}$

\begin{tabular}{|l|l|l|l|l|l|l|l|l|}
\hline Construct & Mean & SD & ID & OD & DJ & IJ & InfoJ & PJ \\
\hline Interpersonal Deviance (ID) & 1.42 & 0.56 & $(.775)$ & & & & & \\
\hline Organizational Deviance (OD) & 1.32 & 0.46 & $.72^{* * *}$ & $(.844)$ & & & & \\
\hline Distributive Justice (DJ) & 3.70 & 0.97 & -.08 & $-.16^{* *}$ & $(.919)$ & & & \\
\hline Interpersonal Justice (IJ) & 3.83 & 0.83 & $-.18^{* *}$ & $-.15^{*}$ & $.52^{* * *}$ & $(.873)$ & & \\
\hline Informational Justice (InfoJ) & 3.88 & 0.82 & $-.21^{* * *}$ & $-.18^{* *}$ & $.44^{* * *}$ & $.70^{* * * *}$ & $(.932)$ & \\
\hline Procedural Justice (PJ) & 3.67 & 0.70 & -.02 & -.04 & $.53^{* * * *}$ & $.55^{* * * *}$ & $.55^{* * *}$ & $(.809)$ \\
\hline
\end{tabular}



${ }^{*} \mathrm{p}<.05,{ }^{* *} \mathrm{p}<.01, * * * \mathrm{p}<.001$

Figure 1 illustrated the structural model, and the structural model was tested in structural equation modelling (SEM) procedure using AMOS. The model yielded a reasonable fit given the data set $\left(\chi^{2} / \mathrm{df}=\right.$ $1.646, \mathrm{GFI}=0.905, \mathrm{AGFI}=0.882, \mathrm{CFI}=0.960, \mathrm{TLI}=0.954, \mathrm{RMSEA}=0.043)$. Table 4a showed that interpersonal justice $(\beta=-0.188, \mathrm{p}<0.05)$ and informational justice $(\beta=-0.23, \mathrm{p}<0.01)$ have significant effects on interpersonal deviance. The two independent variables (interpersonal justice and informational justice) accounted for $11 \%$ of the variance in interpersonal deviance. Table $4 \mathrm{~b}$ showed that distributive justice $(\beta=-0.23, p<0.01)$ and informational justice $(\beta=-0.18, p<0.05)$ have a significant combined effect on organizational deviance, accounting for $10 \%$ of the variance. 


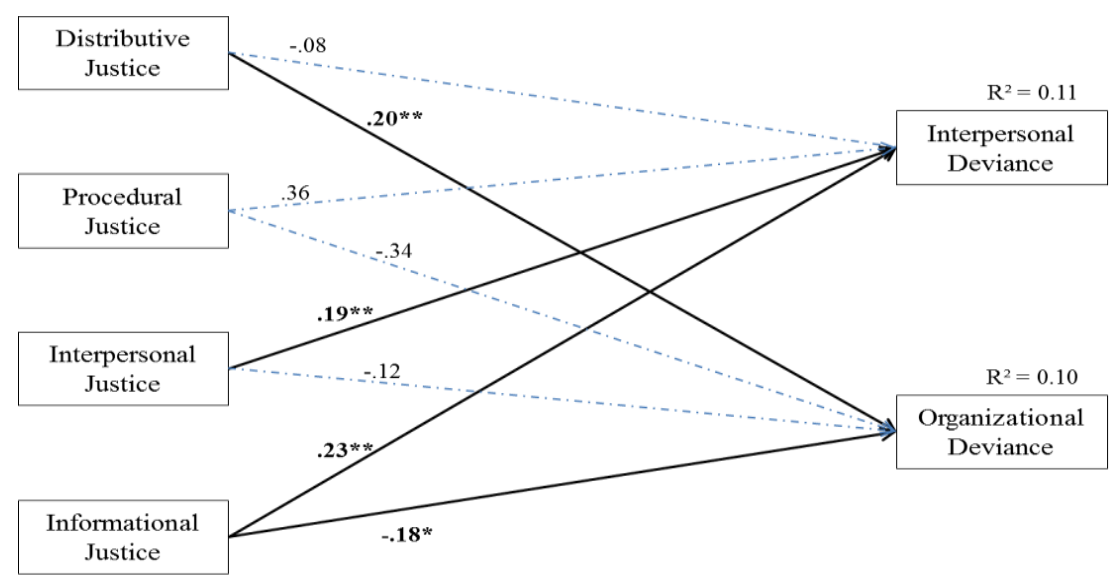

Figure 1. Structural Model

Note: ${ }^{*} \mathrm{p}<0.05 ;{ }^{*} \mathrm{p}<0.01$

Table 4a.

Effects of organizational justice on interpersonal deviance

\begin{tabular}{|l|l|l|l|l|l|l|}
\hline Construct & Estimate & S.E. & Beta & Critical Ratio & P & Decision \\
\hline Distributive Justice & -.052 & .050 & -.077 & -1.030 & .303 & Rejected \\
\hline Interpersonal Justice & -.130 & .061 & -.188 & -2.137 & .033 & Supported \\
\hline Informational Justice & -.151 & .053 & -.225 & -2.864 & .004 & Supported \\
\hline Procedural Justice & .385 & .114 & .362 & 3.364 & .056 & Rejected \\
\hline
\end{tabular}

$\mathrm{R}=0.033, \mathrm{R}^{2}=0.113$

Table 4b.

Effects of organizational justice on organizational deviance

\begin{tabular}{|l|l|l|l|l|l|l|}
\hline Construct & Estimate & S.E. & Beta & Critical Ratio & P & Decision \\
\hline Distributive Justice & -.157 & .058 & -.202 & -2.685 & .007 & Supported \\
\hline Interpersonal Justice & -.092 & .070 & -.116 & -1.316 & .188 & Rejected \\
\hline Informational Justice & -.137 & .061 & -.176 & -2.235 & .025 & Supported \\
\hline Procedural Justice & .414 & .130 & .338 & 3.172 & .200 & Rejected \\
\hline
\end{tabular}

$\mathrm{R}=0.031, \mathrm{R}^{2}=0.098$

\section{Discussion}

The goal of this study is to examine the relationship between the emergency services personnel perception of organizational justice and their likelihood to exhibit employee deviance. Overall, the data set fit reasonably to the hypothesized model. There are few interesting findings from this study. Firstly, is that employee deviance among the emergency services context was found to be bi-dimensional as postulated by Bennett and Robinson (2000) with distinctions emerging between individual and organizational deviance. Second, the organizational justice construct was found to correspond to the four dimensions (Distributive, Procedural, Interpersonal and Informational Justice) as proposed by Colquitt (2001). This is the first study that validated prior findings concerning the construct of employee deviance and organizational justice within a non-Western and emergency services context.

Findings from this study also revealed that interpersonal justice and informational justice are negatively correlated with interpersonal deviance. The results indicated that high levels of respectful interpersonal treatment and candid explanations from their supervisors will reduce the frequency of volunteers engaging in behaviours that directed towards members of the organization. In the emergency services context, Table 4a showed that interpersonal justice and informational justice have a 
moderate effect on Interpersonal Deviance $\left(\mathrm{R}=0.03, \mathrm{R}^{2}=0.113\right)$ (Cohen, 1988). This suggests that when the information provided by the supervisors is properly communicated with their employees, this will moderately influenced their employees to perform positively to the people around them.

On another hand, distributive justice and informational justice were negatively correlated with organizational deviance. The value indicated that high level of distributive justice and informational justice would reduce the occurrence of emergency services personnel from engaging in deviant behaviours that directed towards the organization. Table $4 \mathrm{~b}$ indicated that the effects of distributive justice and informational justice on organizational deviance was moderate $\left(R=0.031, R^{2}=0.098\right)$ (Cohen, 1988). This showed that when the rewards and job demands are fairly dispersed along with an adequate explanation from their supervisors or organization, employees will be less likely to engage in employee deviance. The relationship between individuals' perceptions of the fairness of job demands and rewards distribution and organizational deviance are consistent with findings from Skarlicki and Folger (1997) and Henle (2005). These studies suggest that when a relationship is perceived as unfair, an individual will react to reduce the felt tension to re-establish an internal equilibrium (Ménard et al., 2011).

\section{Managerial Implications}

The results of the present study have important implications for supervisors of the emergency services and policymakers. Given the importance of emergency services in today's world, the results demonstrated that it is necessary for the supervisors to be fair with their employees to build an organization's ability to address the needs of the people in their community. Fairness to the emergency services personnel appears to translate into both employee retention and enhanced emergency services, as individuals are more committed to the organization and its goals. In the context of decreasing the issue of employee deviance amongst the emergency services personnel, interventions aimed at work fairness seem likely to improve positive work outcomes. Therefore, if the emergency services want to improve service efficiency and employee performance, they needs to pay more attention to developing programmes and policies that encourage workplace fairness. Their supervisors and team leaders need to examine organizational justice from the employee's perspective rather to rely solely on their own observations and assessments. In additions, leadership training programme with emphasis on the important of fairness, interpersonal skills, and sharing goals may increase employee's knowledge and skills on the job.

\section{Limitations}

The limitations of this study suggest the directions for future research. First, the sample was from selected emergency services centres, and this setting may be unique enough to limit the external validity of the research findings. Second, self-report measures were chosen in data collections because they provide an efficient, cost-effective and complete information about an individual's deviant behaviours, but this method may subject to common method variance, although the data were randomly collected from different centres. Finally, the cross-sectional research design limits the ability to test the causal inferences of the relationships. Given that organizational justice is concerned with workplace fairness issues, it may be fruitful to consider overall justice perceptions; recent studies showed that overall organizational justice may exert more proximal influence on outcome variables than do specific justice dimensions (Ambrose and Schminke, 2009; Holtz and Harold, 2013). Future research might also consider the interactions of organizational justice dimensions and individual differences variables (e.g., tolerance for ambiguity) on deviance outcomes (Henle, 2005; Liu and Ding, 2012; Skarlicki and Folger, 1997).

Journal of Contemporary Research in Business, Economics and Finance
ISSN: $2641-0265$
Vol. 1, No. 4, pp. $62-73,2019$
DOI: $10.33094 / 26410265.2019 .14 .62 .73$
C) 2019 by the authors; licensee Learning Gate




\section{Conclusion}

Even with the limitations stated above, the research objectives of this study were achieved. First, this study has offered an explanation for which dimensions of organizational justice which predicts employee deviance that either targeted at members of an organization, the organization itself and/or both. The findings have validated the dimensions of organizational justice and employee deviance among the emergency services personnel. In additions, the findings have offered empirical support that interpersonal justice and informational justice are antecedents of interpersonal deviance, while distributive justice and informational justice are predictors of organizational deviance. Though other dimensions of organizational justice may possibly not be the antecedents to employee deviance, this study suggest that actions to promote fairness in process and procedures of decision-making, distributions of job demands and rewards, and the adequacy to provide explanation on tasks execution may be useful in reducing the occurrence of employee deviance.

\section{Acknowledgements}

This research received no specific grant from any funding agency in the public, commercial, or notfor-profit sectors.

\section{References}

Adams, J. S. (1965). Inequity in social exchange. In L. Berkowitz (Ed.), Advances in experimental social psychology (pp. 267-299). New York: Academic Press.

Alias, M., \& Rasdi, R. M. (2015). Organizational Predictors of Workplace Deviance among Support Staff. Procedia - Social and Behavioral Sciences, 172: 126-133. Available at: http://doi.org/10.1016/j.sbspro.2015.01.345.

Ambrose, M. L., \& Schminke, M. (2009). The Role of Overall Justice Judgments in Organizational Justice Research: A Test of Mediation. Journal of Applied Psychology, 94(2): 491-500. Available at: http://doi.org/10.1037/a0013203.

Ambrose, M. L., Seabright, M. A., \& Schminke, M. (2002). Sabotage in the Workplace:The Role of Organizational Injustice. Organizational Behavior and Human Decision Processes, 89: 947-965.

Appelbaum, S. H., Deguire, K. J., \& Lay, M. (2005). The relationship of ethical climate to deviant workplace behaviour. Corporate Governance, 5(4): 43-55. Available at: http://doi.org/10.1108/14720700510616587.

Aquino, K., Lewis, M. U., \& Bradfield, M. (1999). Justice constructs, negative affectivity, and employee deviance: A proposed model and empirical. Journal of Organizational Behaviour, 20(January 1998): 1073-1091. Available at: http://doi.org/10.1002/(SICI)1099-1379(199912)20:7<1073::AID-JOB943>3.0.CO;2-7.

Bauer, J. A., \& Spector, P. E. (2015). Discrete Negative Emotions and Counterproductive Work Behavior. Human Performance, 28(4): 307-331. Available at: http://doi.org/10.1080/08959285.2015.1021040.

Bennett, R. J., \& Robinson, S. L. (2000). Development of a measure of workplace deviance. The Journal of Applied Psychology, 85(3): 349-360. Available at: http://doi.org/10.1037/0021-9010.85.3.349.

Berry, C. M., Ones, D. S., \& Sackett, P. R. (2007). Interpersonal deviance, organizational deviance, and their common correlates: a review and meta-analysis. The Journal of Applied Psychology, 92(2): 410-424. Available at: http://doi.org/10.1037/0021-9010.92.2.410.

Blau, P. M. (1964). Exchange and power in social life. New York: John Wiley \& Sons Ltd.

Chang, K., \& Smithikrai, C. (2010). Counterproductive behaviour at work: an investigation into reduction strategies. The International Journal of Human Resource Management, 21(December): 1272-1288. Available at: http://doi.org/10.1080/09585192.2010.483852.

Cohen, J. (1988). Statistical Power Analysis for the Behavioral Sciences (2nd ed.). New Jersey: Lawrence Erlbaum Associates.

Cohen-Charash, Y., \& Spector, P. E. (2001). The Role of Justice in Organizations: A Meta-Analysis. Organizational Behavior and Human Decision Processes, 86(2): 278-321. Available at: http://doi.org/10.1006.

Colquitt, J. A. (2001). On the dimensionality of organizational justice: A construct validation of a measure. Journal of Applied Psychology, 86(3): 386-400.

Journal of Contemporary Research in Business, Economics and Finance
ISSN: 2641 -O265
Vol. 1, No. 4, pp. $62-73,2019$
DOI: $10.33094 / 26410265.2019 .14 .62 .73$
C) 2019 by the authors; licensee Learning Gate


Colquitt, J. A., Conlon, D. E., Wesson, M. J., Porter, C. O. L. H., \& Ng, K. Y. (2001). Justice at the millenium: a meta-analytic review of 25 years of organizational justice research. Journal of Applied Psychology, 86(3): $425-445$.

Cropanzano, R., \& Mitchell, M. (2005). Social Exchange Theory: An Interdisciplinary Review. Journal of Management, 31(6): 874-900.

Deconinck, J. B., \& Johnson, J. T. (2013). The Effects of Perceived Supervisor Support, Perceived Organizational Support, and Organizational Justice on Turnover among Salespeople. Journal of Personal Selling \& Sales Management, 29(4): 333-350. Available at: http://doi.org/10.2753/PSS0885-3134290403.

El Akremi, A., Vandenberghe, C., \& Camerman, J. (2010). The role of justice and social exchange relationships in workplace deviance: Test of a mediated model. Human Relations, 63: 1687-1717. http://doi.org/10.1177/0018726710364163.

Greenberg, J. (1990). Organizational justice: yesterday, today and tomorrow. Journal of Management, 16(2): 399432.

Greenberg, J. (1993a). Stealing in the name of justice: Informational and interpersonal moderators of theft reactions to underpayment inequity. Organizational Behavior and Human Decision Processes, 54: 81-103.

Greenberg, J. (1993b). The social side of fairness: Interpersonal and Informational classes of organizational justice. In R. Cropanzano (Ed.), Justice in the Workplace Approaching Fairness in Human Resource Management (pp. 79-103). Hillsdale, N.J.: Erlbaum.

Greenberg, J. (1994). Using socially fair treatment to promote acceptance of a work site smoking ban. Journal of Applied Psychology, 79(2): 288-297.

Hair, J. F., Anderson, R. E., Tatham, R. L., \& Black, W. C. (2010). Multivariate Data Analysis: A Global Perspective (7th ed.). Upper Saddle River, New Jersey: Pearson.

Hassan, A., \& Hashim, J. (2011). Role of Organizational Justice in determining work outcomes of national and expatriate academic staff in Malaysia. International Journal of Commerce and Management, 21(1): 82-93. Available at: http://doi.org/10.1108/10569211111111711.

Hemdi, M. A., \& Aizzat, M. N. (2006). Organizational Justice and Deviant Behaviour in the Hotel. In TEAM Journal of Hospitality \& Tourism, 3: 31-40.

Henle, C. A. (2005). Predicting Workplace Deviance from the Interaction between Organizational Justice and Personality. Journal of Managerial Issues, 17(2): 247-263.

Holtz, B. C., \& Harold, C. M. (2013). Interpersonal Justice and Deviance: The Moderating Effects of Interpersonal Justice Values and Justice Orientation. Journal of Management, 39(2): 339-365. Available at: http://doi.org/10.1177/0149206310390049.

Judge, T. A., Scott, B. A., \& Ilies, R. (2006). Hostility, job attitudes, and workplace deviance: test of a multilevel model. The Journal of Applied Psychology, 91(1): 126-138. Available at: http://doi.org/10.1037/00219010.91.1.126.

Lim, V. K. G. (2002). The IT way of loafing on the job : cyherloafing, neutralizing and organizational justice. Journal of Organizational Behavior, 23: 675-694. http://doi.org/10.1002/job.161.

Liu, N.-T., \& Ding, C. G. (2012). General ethical judgments, perceived organizational support, interactional justice, and workplace deviance. The International Journal of Human Resource Management, 23(October 2014): 2712-2735. Available at: http://doi.org/10.1080/09585192.2011.610945.

McCain, S. L. C., Tsai, H., \& Bellino, N. (2010). Organizational justice, employees' ethical behavior, and job satisfaction in the casino industry. International Journal of Contemporary Hospitality Management, 22(7): 992-1009. Available at: http://doi.org/10.1108/095961110110666644.

Ménard, J., Brunet, L., Savoie, A., van Daele, A., \& Flament, A. (2011). Crossnational deviance in the workplace: Diverging impact of organizational commitment in Canada and Belgium. European Journal of Work and Organizational Psychology, 20(2): 266-284. Available at: http://doi.org/10.1080/13594320903432315.

Moorman. (1991). Relationship between organizational justice and organizational citizenship behaviors: Do fairness perceptions influence employee citizenship? Journal of Applied Psychology, 76(6): 845-855.

Narveson, J. (2006). Justice in health care. Journal of Value Inquiry, 40(2-3): 371-384. Available at: http://doi.org/10.1007/s10790-007-9051-2.

Nasurdin, A. M., Ahmad, N. H., \& Razalli, A. A. (2014). Politics, Justice, Stress, and Deviant Behaviour in Organizations: International Journal of Business and Society, 15(2): 235-254.

Niehoff, B. P., \& Moorman, R. H. (1993). Justice as a mediator of the relationship between methods of monitoring and organizational citizenship behavior. Academy of Management Journal, 36: 527-556.

Journal of Contemporary Research in Business, Economics and Finance
ISSN: $2641-0265$
Vol. 1, No. 4, pp. $62-73,2019$
DOI: $10.33094 / 26410265.2019 .14 .62 .73$
C) 2019 by the authors; licensee Learning Gate


O’Boyle, E. H., Forsyth, D. R., Banks, G. C., \& McDaniel, M. A. (2012). A meta-analysis of the Dark Triad and work behavior: A social exchange perspective. Journal of Applied Psychology, 97(3): 557-579. Available at: http://doi.org/10.1037/a0025679.

O’Neill, T. A., Lewis, R. J., \& Carswell, J. J. (2011). Employee personality, justice perceptions, and the prediction of workplace deviance. Personality and Individual Differences, 51(5): 595-600. Available at: http://doi.org/10.1016/j.paid.2011.05.025.

Parzefall, M.-R., \& Salin, D. M. (2010). Perceptions of and reactions to workplace bullying: A social exchange perspective. Human Relations, 63: 761-780. Available at: http://doi.org/10.1177/0018726709345043.

Peng, H. (2008). Counterproductive Work Behavior Among Chinese Knowledge Workers, 20(2).

Roch, S. G., \& Shanock, L. R. (2006). Organizational Justice in an Exchange Framework: Clarifying Organizational Justice Distinctions. Journal of Management, 32(2): 299-322. Available at: http://doi.org/10.1177/0149206305280115.

Settoon, R. P., Bennett, N., \& Liden, R. C. (1996). Social exchange in organizations: Perceived organizational support, leader-member exchange, and employee reciprocity. Journal of Applied Psychology, 81(3): 219227. Available at: http://doi.org/10.1037/0021-9010.81.3.219.

Skarlicki, D. P., \& Folger, R. (1997). Retaliation in the workplace: The roles of distributive, procedural, and interactional justice. Journal of Applied Psychology, 82(3): 434-443. Available at: http://doi.org/10.1037/0021-9010.82.3.434.

Tabachnick, B. G., \& Fidell, L. S. (2013). Using Multivariate Statistics. 6th Edn., Boston: Pearson.

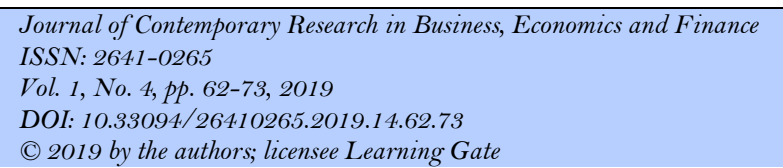

